\title{
Parliamentary Questions: Expressions of Opposition(s) within the European Parliament?
}

\author{
Petr Kaniok \\ Magda Komínková \\ Department of International Relations \\ and European Studies, \\ Faculty of Social Science, \\ Masaryk University \\ Jostova 10 , \\ Brno 602 00, Czech Republic \\ E-mail: kaniok@fss.muni.cz \\ E-mail:363737@mail.muni.cz
}

\begin{abstract}
Parliamentary questions are a direct form of parliamentary scrutiny of other EU institutions and bodies, traditionally being an important tool for the opposition. This study examines how parliamentary questions are used in the European Parliament. We ascertain whether political groups representing opposition differ in their use of parliamentary questions from those who are represented in the European Commission. The article presents two main findings. First, such a difference does exist in all types of questions at the aggregated level. Groups not represented in the European Commission pose more questions than those who are represented. Secondly, it appears that the type of parliamentary question determines the groups 'behaviour. The article thus contributes to our understanding of how opposition functions in the European Parliament.
\end{abstract}

Keywords: European Parliament, MEPs, opposition, parliamentary questions, parliamentary scrutiny, political groups in the EP, supervisory powers 


\section{Introduction}

A number of studies in recent years have pointed out that the character of political competition in the European Parliament (EP) is becoming similar to that in national parliaments. In particular, scholars have highlighted the growing importance of traditional left-right contests, and of the European cleavage, at the expense of the previously dominant voting along national lines (e.g., Crespy \& Gajewska, 2010; Demker, 2014; Volacu, 2012; Bressanelli, 2013; Hobolt, 2015).

An important precondition of fully-fledged party competition in any parliamentary body is the presence of an opposition and of political formations supporting the executive. Typically, some parties are in government and support its work in parliament, whereas the opposition seeks to scrutinise the government and to obtain executive power. Matters are not so straightforward in the political system of the European Union (EU), however. European elections do not lead directly to government formation, however the 2014 elections to the EP introduced a new procedure to elect the President of the European Commission (hereafter, Commission), the so-called Spitzenkandidaten ${ }^{1}$. The Lisbon Treaty states:

\section{Taking into account the elections to the European Parliament and after having held the appropriate consultations, the European Council, acting by a qualified majority, shall propose to the European Parliament a candidate for President of the Commission. (Article 17 of the TEU).}

Lead candidates/a candidate for President of the European Commission have linked the EP and the Commission more closely. One of the reasons for the change in the practice of appointing Spitzenkandidaten is to increase the legitimacy of the Commission.

One may identify political groups in the EP that find the make-up of the Commission congenial (not least because some of its members are of the same

\footnotetext{
Our analysis concerns the pre-Lisbon Treaty period. However, the Barroso Commissions claimed to be anticipations of the Spitzenkandidaten provisions in the Constitutional Treaty/Lisbon Treaty. The idea of introducing a legal link between the composition of the future Parliament and nominating candidates for Commission president appeared to be the compromise acceptable to all parties involved in the Convention deliberations. According to the draft elaborated in Estoril and tabled by the European People's Party, personalisation aimed to ensure greater democratic legitimacy of the Commission. Moreover, the idea of personalisation was elaborated in the 1990s by Jacques Delors (Gostyńska, 2014).
} 
party family) as well as others which might be described as being in opposition to the Commission. It means those political groups that are not directly represented at a political level within the Commission College. Unlike that of a national parliament, the opposition in the EP has to focus largely on the business of scrutiny. The questions then are: what instruments does the opposition in the EP have at its disposal for such scrutiny, how does it use them, do these instruments serve to conceptualise opposition in the EP and, if so, how?

This article tries to offer answers to these questions by an analysis of parliamentary questions in the EP. Various important actors or arenas could be identified in the EP: the plenary sitting, and majorities within it; the Committees; other groupings (intergroups, etc); the individual MEPs and especially the political groups. We analyse political groups because they are homogeneous political subjects that we know from parliamentary democracies as parliamentary factions of political parties. Political groups are associations of politically like-minded national political parties. Generally, political groups are perceived as very powerful inside the EP (Finke, 2014). Through their analysis, we seek to address three problems. First, are there differences among political groups in how they use the questions as a tool? That means, are there differences between political groups supporting the Commission and those opposing it? Second, because there are several types ${ }^{2}$ of parliamentary questions in the EP, we aim to reveal whether they are used differently and what these potential differences tell us. Third, we are interested to know whether medium-term trends can be ascertained in the use of parliamentary questions. To answer these questions, we analyse the dataset we have put together, consisting of all parliamentary questions posed during the terms 2004-2009 and 2009-2014. ${ }^{3}$

Our main finding is that opposition and "governmental" roles can be discerned in the EP in connection with the parliamentary questions that have been posed, but much depends on how these questions are analysed. At the aggregated level-i.e. when all questions are included-political groups differ in their asking of these questions, depending on whether they belong to the so-called "grand coalition" that is represented in the Commission, or whether they can be considered part of the opposition camp. However, descending to the analytical level of individual types of questions, this finding is no longer true. First, as far as oral questions are concerned, the behaviour of both camps changed between the terms 2004-2009

2 Individual MEPs cannot use all types of questions - only some, as set out in the Rules of Procedure of the EP.

3 There are two reasons to choose this term. First, it is the last completed term preceding the current one. Second, it is a term subsequent to the great EU enlargement that admitted Central and Eastern European countries. 
and 2009-2014. Whereas in the former term the opposition was more active, in the latter the groups represented in the Commission posed more questions. For questions posed during Question Time, no difference could be found between opposition and "government" groups in either term. It is in written questions, then, that a difference between opposition and pro-European Commission groups can be identified. Written questions evidently provide the bulk of the total number of questions posed in the EP and their number has increased over time; these facts testify to their importance. Our analysis contributes to research about how MEPs and political groups act. Although largely exploratory and leading to further questions rather than providing strong explanations, the paper helps us to understand whether and how a classic form of competition between government and opposition is emerging in the EP.

The article proceeds as follows. The next section presents the state of the art as far as opposition in the EP is concerned. The following section describes the data and classifies the political groups active in the EP during the two terms examined, presenting also our method. The next section consists of the analysis and provides answers to our questions. In the concluding section, we discuss our findings with existing knowledge and suggest avenues for further research.

\section{Opposition in the European Parliament: A specific kind of power?}

Since there is no special theory ${ }^{4}$ that would define and explain the workings of opposition in the EP, we proceed from the theory of opposition ${ }^{5}$ that has been primarily devised for parliamentary democracies. According to this theory, the opposition should scrutinise and criticise the government, but also articulate and aggregate interests, and seek to gain a share of power. Parliamentary questions, the subject of this article, fall into the category of scrutiny.

The opposition in the EP does not work in the same way as in national parliaments. There is no clearly defined relationship between the executive and the legislative

4 We do not mean theories explaining European integration as such.

5 Various attempts have been made in political science to provide a definition of opposition that would be universally valid (Kubát, 2010, p. 17). A classic example is that of Dahl, who described opposition on the basis of the alternation of groups in power. A group governing at any given point might later become opposition, and opposition, by contrast, might come to power. Democracy is secured when the opposition is able to take power, but only on the basis of democratic elections. Unlike most others, Dahl's definition can be applied to any political system (Dahl, 1966, pp. 336-339). 
branches as exists in parliamentary democracies (Corbett, Jacobs \& Shackleton, 2011, p. 122). Our basic premise is that opposition can be identified in the EP and that it constitutes a specific kind of power. In literature, there are two basic views of opposition in the EP. The first sees it as opposition to the EU, and the second as opposition to the Commission.

The most comprehensive analysis of opposition in the EP to date has been provided by Helms (2008), who studied opposition in both nation states and the EU. Helms concluded that opposition in the EP can be studied, but that the activities of opposition MEPs are largely informed by the national level. Helms argues that, despite the options available to opposition, there is no government (European Commission) alternation, as Dahl (1966) and others would expect to take place. According to Helms, the opposition in the EP is weak, and it does not fulfil the functions it might exercise. Helms explains the workings of the EU by a multi-level model of checks and balances, involving a large number of various actors. Greater politicisation of EU institutions, Helms argues, would solve the problem, allowing for a more efficient functioning of government and opposition alike (Helms, 2008, pp. 212-235).

Navarro (2010) not only analysed opposition in the EP in general, but also tangentially touched upon parliamentary questions which, he argues, can be used by opposition MEPs to attack government and obtain information. Navarro considers the Commission a government, consisting of a grand coalition, supported sometimes by other parliamentary factions such as the Greens. He considers the remaining parties as the opposition, i.e. he defines opposition via the sharing of power (Navarro, 2010, pp. 15-16). Brack (2012) offers another view, defining the opposition on the basis of parties' approaches towards the European integration, and describing the hard Eurosceptics as the opposition. According to Brack, party Euroscepticism and opposition in the EP are interconnected (Brack, 2012, pp. 51-67). Both positions are brought together by Leconte, suggesting that Eurosceptics have little influence over the formation of the college of commissioners, which means that they have virtually no power in the Commission (Leconte, 2010, p. 15).

The concept of opposition plays a significant role in research on parliamentary questions in the EP. There are three reasons why MEPs submit questions: to gain information, to scrutinise or to obstruct. Having studied parliamentary democracies, Wiberg (1994) presented a range of motivations that might lead to a question being posed. Members of national parliaments (rather than MEPs specifically) might ask to obtain information, support a certain activity, gain personal publicity, ask for an explanation of some activity, attack ministers 
in a complicated political situation, present various interests, build their own reputation on certain specific questions, push the government towards compromise, delay a government decision, point out mistakes, gather opposition forces to attack the government or render the situation more dramatic (Wiberg, 1994, pp. 30-31). This catalogue, however, is primarily linked with parliamentary democracies, precluding its application to MEPs. Navarro (2010), analysing why MEPs pose questions, highlighted their attempts to be re-elected. He argues that politicians ask questions in order to get re-elected, obtain a leadership position or influence policy. There are also situations when MEPs themselves are not particularly invested in the questions, but act as proxies for interest groups, lobbyists, civil servants of their nation state or their constituents. There might even be a situation in which Commission officials prepare the question, which the MEP then submits to the Commission, allowing it to defend its position (Judge \& Earnshaw, 2008, pp. 219-221).

Each type of question presented above can be variously motivated. These are primarily dependent on the case, for which a particular type of question might be suitable or not, and on the type of information. Should MEPs wish to pose a question, they must consider which type is the most suitable for their particular situation. Addressing the following four points might help them to do so: (1) Is the question urgent or not? (2) Is it important which specific person should answer the question? (3) Is further discussion required? (4) Do the inquirers wish to influence other actors? (Sánchez de Dios \& Wiberg, 2011, p. 356). ${ }^{6}$ The answers should suggest which type of question is the most suitable. A choice of the correct type of question is the first step towards satisfying the inquirer.

The varying motivations for and effects of posing a question play an important role in choosing the type of question. Papers studying the use of parliamentary questions most often analyse their individual types and confirm that there are differences in how they are used (Westlake, 1994; Corbett, Jacobs \& Shackleton, 2011; Raunio, 1996; Meijer, 2001; Judge \& Earnshaw, 2008; Sánchez de Dios \& Wiberg, 2011; Jensen, Proksch \& Slapin, 2013; Navarro, 2010; Russo \& Wiberg, 2010; Sozzi, 2016). Typically, there is a difference between oral and written questions. The former is particularly suitable when the issue under question is broad and the involvement of a wide spectrum of actors is desired, since the purpose of these questions is to address a wider audience and to express a general position. Written questions are usually addressed to a more specific audience and are more specialised (Rozenberg \& Martin, 2011). By contrast, Question

6 A selection of some questions as proposed by Sánchez de Dios and Wiberg. We have selected questions that might be relevant for MEPs (Sánchez de Dios \& Wiberg, 2011, p. 356). 
Time can be efficiently used by MEPs to inform their colleagues about a topic on which they are focused, or if they want to attract attention to themselves.

Table 1. Choosing the type of question

\begin{tabular}{|l|c|c|c|c|}
\hline & Urgency & Who answers & $\begin{array}{c}\text { Further } \\
\text { discussion }\end{array}$ & $\begin{array}{c}\text { Influence on } \\
\text { other actors }\end{array}$ \\
\hline $\begin{array}{l}\text { For oral } \\
\text { answer } \\
\text { (type O) }\end{array}$ & Yes & Committee member & $\begin{array}{c}\text { May take } \\
\text { place }\end{array}$ & $\begin{array}{c}\text { Public } \\
\text { discussion } \\
\text { possible }\end{array}$ \\
\hline $\begin{array}{l}\text { For written } \\
\text { answer (types } \\
\text { P and E) }\end{array}$ & No & $\begin{array}{c}\text { Questions } \\
\text { addressed to } \\
\text { specific individuals }\end{array}$ & No & $\begin{array}{c}\text { Published } \\
\text { officially, } \\
\text { potential future } \\
\text { impact }\end{array}$ \\
\hline $\begin{array}{l}\text { At question } \\
\text { time } \\
\text { (type H) }\end{array}$ & Yes & $\begin{array}{c}\text { Selected European } \\
\text { Commission } \\
\text { representatives only }\end{array}$ & $\begin{array}{c}\text { May take } \\
\text { place }\end{array}$ & $\begin{array}{c}\text { Possible } \\
\text { involvement of } \\
\text { other MEPs }\end{array}$ \\
\hline
\end{tabular}

Source: Authors (modified from Sánchez de Dios \& Wiberg, 2011)

We assume that the different manner in which questions are used will also be manifested in the relationship between the opposition and government. Our argument is supported by the work of Brack (2012; 2015). Though not primarily focused on parliamentary questions, her analysis of hard Eurosceptic groups touches upon the issue. Brack proceeded from Hirschman's (1970) work and devised four ideal types describing the roles in which Eurosceptics might act in the EP. These are: the absentee (exit strategy); the pragmatist, who is involved in the EP and actively uses their right to vote (voice strategy) $;^{7}$ the public orator, whose aim is to achieve public exposure and, potentially, to spread negative views on the EU, and the participant, who seeks consensus, influence in committees, and also makes use of informal procedures. According to Brack's findings, public orators make more use of the option to ask questions and to talk at plenary sessions (Brack, 2012).

Sozzi (2016) studied how MEPs use parliamentary questions, focussing on several variables that might influence questioning. Sozzi studied both the national and supranational aspects of the issue and examined the effects of

7 Brack argues that hard Eurosceptics do not participate in the work of the EP and do not use the options at their disposal. However, an interview-based study has shown that Eurosceptic MEPs do use parliamentary questions for written answers, by means of which they defend the interests of their constituents. Pragmatically-minded Eurosceptics employ a range of instruments made available to them by the EP. 
electoral systems, as well as of the environment from which MEPs originate. Sozzi noted that British MEPs make more use of parliamentary questions, due to the substantial tradition of the device in their country. He sees questions as a tool that MEPs may use to improve their reputation and build up their political image. The results of Sozzi's analysis, based on data from the sixth electoral term, partially support Raunio's (1996) assumption that smaller and less relevant groups use questions more often. This was proven for the leftist group GUE. However, Sozzi does not analyse all questions, limiting himself to two types, written and oral. Furthermore, he also included questions to the Council in his study.

To sum up, existing research suggests that there is no agreement on how the opposition in the EP should be defined and how it uses its power. That is particularly visible when it comes to the parliamentary questions. Up-to-date work is in this regard rather fractured and often addresses only fragments of the oppositional behaviour in non-systematic way. Our aim is to fill this gap by a comprehensive analysis of two EP's terms. Two disclaimers have to be stated here. First, we assume that the Commission can be conceptualised as part-executive (the European government); however, we are aware of that the European Council also exercises executive powers to some extent. ${ }^{8}$ Division of executive powers between these two institutions, however, is not symmetric as the European Council is not active in day-to-day politics and does not shape the same amount of EU policies as the Commission does. Second, we are aware that our article analyses only a certain segment of the powers given to the opposition. We are aware of that opposition may use various instruments (votes, budgetary procedure, election of the Commission) at the disposal of different actors within the EP. We analyse a part of them, which means that the article does not provide a comprehensive study of how the opposition works in the EP and rather analyses some of its activities, suggesting how this opposition is to be understood.

8 The Commission is the principal executive body of the EU. Despite, the European Council has executive powers to some extent. The European Council is composed of national leaders, it gathers the executive power of the Member States and, thus, has influence on high-profile policy. The European Council decides on the EU's overall direction and political priorities. Setting the EU's common foreign and security policy is important for the European Council. The European Council nominates and appoints candidates to certain high-profile EU level roles (such as the ECB). 


\section{Data and methods}

MEPs pose parliamentary questions to the Commission and the Council of the EU. Via these questions, MEPs, committees and political groups in the EP can scrutinise the Commission and the Council, obtain information, and highlight issues both at the EU and national levels. Parliamentary questions can also be used as a specific form of obstruction (Jensen, Proksch \& Slapin, 2013). They provide opposition MEPs with a suitable instrument with which to scrutinise the Commission.

Each calendar year, the EP poses some 7,000-11,000 questions to the Commission and the number has increased every year. However, this growth does not apply to every type of question, as will be shown below. Parliamentary questions have been linked with the institutional framework of the EU for a long time. The MEP's right to ask, and the Commission's obligation to answer, was established as far back as the ECSC Treaty, Article 23 of which stipulated that the High Authority shall reply to all oral or written questions posed by the Assembly or its members, and the procedure has not changed much since then.

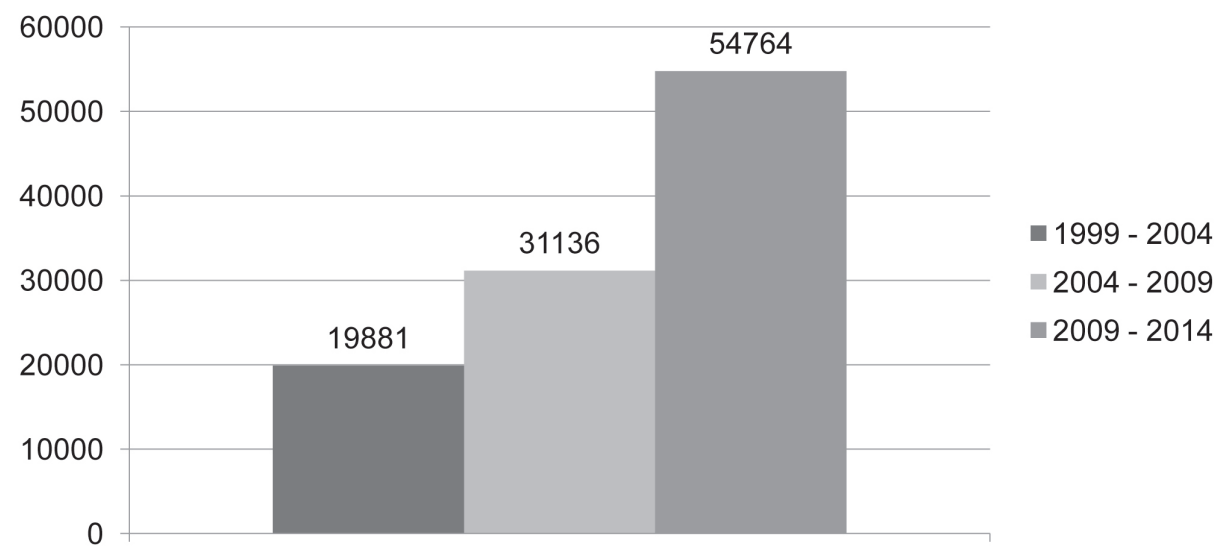

Figure 1. Total number of questions from 1999 to 2014

Source: Authors (European Parliament, 2014)

Figure 1 shows that the number of questions asked has increased and between the sixth (2004-2009) and seventh (2009-2014) electoral terms the number grew by nearly 24,000 . For illustration, we also provide data for $1999-2004 .{ }^{9}$ The growth in the number of questions can be explained by the increase in the number of

9 It is worth noting that in 1999-2004 the EP was a smaller body, with 626 MEPs. 
MEPs, and by extra powers being given to the EP, which strengthened that body's position. Navarro claims, however, that there is no single factor explaining the gradual increase in the number of questions posed; rather, multiple factors are involved (Navarro, 2010).

There are three basic types of questions and their rules are set by the Rules of Procedure of the EP. The first comprises questions to be answered orally with debate (Oral questions/Question for oral answer-type O). They may be followed by a resolution. Such questions can be posed by 40 or more MEPs, by a committee or by a political group (Article 128 of the Rules of Procedure of the EP). MEPs use these questions when they wish to discuss draft legislation of the EC, fundamental EU issues or questions of international interest. Type $\mathrm{O}$ questions are asked when the issue under scrutiny demands the involvement of a greater number of participants and a broader discussion than questions answered in writing (Švecová, 2010, pp. 30-31). The fact that oral questions demand the involvement of a greater number of MEPs can be seen as a disadvantage, as it precludes individual MEPs from asking such questions on their own.

The second type are questions requiring a written answer (Written questions/ Question for written answer), with two sub-types, priority (P) and non-priority (E) questions. Defined in Article 130 of the EP's Rules of Procedure, written questions are among those most often asked. An MEP may submit a maximum of five such questions per month. Non-priority questions should be answered within six weeks, but that limit is often exceeded. If MEPs wish to receive a quick answer, and this does not require detailed research, they may submit a priority question, which should be answered in three weeks. One such question is allowed per MEP per month. In his study, Raunio emphasises the advantage of written questions for those MEPs who wish to avoid direct interaction, as submitting questions in writing allows them to avoid speaking out. He also notes that many questions are posed repeatedly, which may indicate either an attempt to show that the matter is urgent, or to highlight that there has not been an acceptable change or shift in the agenda. According to Raunio, there are two basic reasons for submitting questions that require written responses: to scrutinise the Commission and to obtain information (Raunio 1996, pp. 361364). A significant advantage of questions demanding written answers is that MEPs receive an official statement from the Commission, which is publicly accessible and can be referred to in the future. Written questions are used to gain information about sensitive issues, and where more detailed work is needed to prepare the answer. They are also used when EU law has been contravened, and if MEPs demand detailed technical information (Švecová, 2010 , p. 27).The third type of questions is comprised of those asked during 
Question Time (Question for Question Time-type H). One or more topics, which are set by the Conference of Presidents a month ahead, may be discussed during Question Time. ${ }^{10}$ Two or three commissioners, whose portfolios relate to the given horizontal topic (Article 129 of the EP's Rules of Procedure), answer the questions. The motive for asking questions during Question Time is not so much to gain information as to scrutinise the Commission or to spark debate. The procedure, held at the Strasbourg sessions, is among the most controversial and least understood. Obvious disadvantages include the limited scope of topics that can be queried: one cannot ask for specific or statistical data, etc. The limited number of commissioners means that selected commissioners speak for the whole Commission, often on topics that are not directly part of their portfolios (Raunio, 1996, p. 359). Although these questions have long been part of EU primary law, and are used often, they have not been given sufficient attention, remaining on the margins of interest of EP studies.

EP political groups represent the second "kind" of data we are analysing. We have analysed their behaviour in the two most recent electoral terms. In the sixth term (2004-2009) there were seven groups in the EP, alongside a group of non-attached MEPs. As indicated above, we consider those political groups which do not have influence in the Commission to be opposition. During the sixth term these included GUE/NGL, IND\&DEM, G-EFA and UEN, because in addition to independent commissioners, there were also those affiliated with EPP-ED, PES and ALDE. In the next term, the political make-up of the Commission did not change. EPP, SD and ALDE had their representatives in the Commission. Thus, for the 2009-2014, term we consider the following groups to constitute the opposition: ECR, GUE/NGL, G-EFA and EFD (Corbett, Jacobs \& Shackleton, 2011; Bressanelli, 2012; Akbaba, 2014, Finke, 2015). Although non-attached MEPs often belong to the opposition (extreme right-wing parties, for instance) we have excluded non-attached MEPs from our analysis as they do not constitute an organised group of MEPs in the strict

10 Question Time with the Commission may be held at each part-session for a duration of up to 90 minutes on one or more specific horizontal themes to be decided upon by the Conference of Presidents one month in advance of the part-session. The Member shall be given one minute in which to formulate the question and the Commissioner two minutes in which to reply. That Member may put a supplementary question, lasting no longer than 30 seconds and having a direct bearing on the main question. The Commissioner shall then be given two minutes in which to give a supplementary reply. Rule 129 states: "Question time shall not be specifically allocated in advance. The President shall, as far as possible, ensure that Members that hold different political views and that come from different Member States are given the opportunity to put a question in turn." (Rule of Procedure of the European Parliament 129). 
sense of the word. ${ }^{11}$ We are, of course, aware that there are other possibilities which could be used as a cutting point. For example, voting in motion of (no) confidence could be such a case, or position of a particular national partymember of an EP political group-within its domestic political system. However, both these choices are not without major problems. When it comes to the former, negative voting (or abstention) in confidence vote ${ }^{12}$ could be just a symbolic act which does not exclude future intensive support for policy proposals. The latter perspective is even more problematic. Though the Commission is partly appointed by the national governments via the European Council — and one could thus expect that candidates supported by the national governments are nominated-its policy arena is a European level, not the national. Therefore, we believe that our decision to link opposition in the EP with non-representation in the Commission is the least bad choice.

The analytical section of the article first presents the structure of parliamentary questions, which we subsequently analyse with the aim of ascertaining what differences there might be between political groups. Our original intention was to use the analysis of variance (ANOVA), ascertaining thereby whether some groups pose questions more frequently than others, to a degree that is statistically significant. In other words, we wished to find out using ANOVA whether political groups could be divided into two coherent clusters, the opposition and the government, as expected from their relationship towards the Commission. ANOVA proved impossible to use, however, as it expects the groups being compared to be roughly of the same size, and the values achieved by the individual units within them to show no great variance. The descriptive overviews of data for the two terms, provided in Tables 2 and 3, demonstrate that neither assumption was true, as also confirmed by Levene's test carried out in both cases. Its values of high statistical significance show that the groups are not numerically comparable, and that there is no normal distribution of parliamentary questions among their members.

11 Moreover, oral questions may be tabled by a political group, a committee or at least 5 per cent of Parliament's component Members (38) (Rule of Procedure of the European Parliament 128). Not only for technical and statistical reasons we have excluded non-attached MEPs.

12 Even if we used voting in confidence vote for both terms, we would stick to the same divisions. For the 2004-2009 term, the Commission was backed up by EPP (239 for, 1 against, 19 abstentions), PES (123-29-31), ALDE (59-0-0), UEN (16-1-7). Remaining groups voted in majority against the Commission: G-EFA (0-40-0), IND/ DEM (0-28-3), GUE/NGL (0-34-0), NI (12-16-1). For the 2009-2014 Commission, supportive majority consisted of EPP (243-2-2), S\&D (164-13-1), ALDE (74-6-0), whereas the opposition were represented by ECR (0-1-50), GUE/NGL (2-31-2), EFD (0-14-15), NI (3-21-2), G-EFA (2-51-2). 
Table 2. Numerical strength and distribution of values within groups, 2004-2009

\begin{tabular}{|l|c|c|c|}
\hline Group & N & Minimum & Maximum \\
\hline NI (Non-Inscrits) & 33 & 0 & 853 \\
\hline PES (Party of European Socialists) & 216 & 0 & 1,071 \\
\hline $\begin{array}{l}\text { EPP-ED (European People's Party and } \\
\text { European Democrats) }\end{array}$ & 292 & 0 & 353 \\
\hline $\begin{array}{l}\text { G-EFA (The Greens and European Free } \\
\text { Alliance) }\end{array}$ & 43 & 3 & 414 \\
\hline UEN (Union for Europe of the Nations) & 31 & 3 & 703 \\
\hline $\begin{array}{l}\text { GUE/NGL (European United Left and } \\
\text { Nordic Green Left) }\end{array}$ & 41 & 1 & 980 \\
\hline $\begin{array}{l}\text { ALDE (Alliance of Liberals and Democrats } \\
\text { for Europe) }\end{array}$ & 100 & 0 & 461 \\
\hline IND/DEM (Independence and Democracy) & 36 & 0 & 2,015 \\
\hline Total & 792 & 0 & 2,015 \\
\hline Levene: 11.89 ( $p<0.01$ ) & & & \\
\hline
\end{tabular}

Source: Authors

Table 3. Numerical strength and distribution of values within groups, 2009-2014

\begin{tabular}{|l|c|c|c|}
\hline Group & N & Minimum & Maximum \\
\hline NI (Non-Inscrits) & 29 & 0 & 671 \\
\hline $\begin{array}{l}\text { S\&D (Progressive Alliance of Socialists and } \\
\text { Democrats) }\end{array}$ & 196 & 0 & 1,229 \\
\hline EPP (European People's Party) & 276 & 0 & 1,493 \\
\hline $\begin{array}{l}\text { G-EFA (The Greens and European Free } \\
\text { Alliance) }\end{array}$ & 57 & 6 & 954 \\
\hline $\begin{array}{l}\text { ECR (European Conservatives and } \\
\text { Reformists) }\end{array}$ & 57 & 2 & 728 \\
\hline $\begin{array}{l}\text { GUE/NGL (European United Left and } \\
\text { Nordic Green Left) }\end{array}$ & 36 & 2 & 910 \\
\hline $\begin{array}{l}\text { ALDE (Alliance of Liberals and Democrats } \\
\text { for Europe) }\end{array}$ & 86 & 1 & 1,018 \\
\hline EFD (Europe of Freedom and Democracy) & 28 & 5 & 1,389 \\
\hline Total & 765 & 0 & 1,493 \\
\hline Levene: 9.56 ( $p<0.01)$ & & & \\
\hline
\end{tabular}

Source: Authors 
The nature of the data logically suggested non-parametric testing. We have opted for the Kruskal-Wallis test, which includes a post-hoc Mann-Whitney test (Field, 2009, pp. 559-568). The problem with the Kruskal-Wallis test is that it can tell us whether there are differences between the groups but is unable to distinguish between which groups there is a difference and how large it is. Given the need to compare groups with each other, the use of a post-hoc test is not suitable: due to the number of groups (and the related number of tests needed), we would put the analysis at risk of type II error, because when using the Bonferroni correction we could not consider any coefficients with $\mathrm{p}<0.01$ to be statistically significant. ${ }^{13}$

Given that we expected the government and opposition groups to behave differently, we have recoded political groups into a binary variable, expressing belonging to the opposition or the Commission majority, respectively. We have analysed our data using a series of Mann-Whitney tests, which provide a non-parametric alternative to $t$ tests. Having recoded political groups into the new variable, there nevertheless remained a non-normal distribution of data, precluding parametric tests; hence our series of Mann-Whitney tests. Since our aims included, among other things, a comparison of consistency of opposition behaviour in the two electoral terms, our analysis proceeds according to the type of question, and not according to parliamentary terms.

\section{Analysis}

As noted in Section 2 above, there are three types of parliamentary questions, of which we provide an overview in Table 4. A comparison of the two EP terms analysed reveals that in the 2009-2014 term the number of questions increased by 76 per cent compared with the previous term. The bulk of this increase is accounted for by questions for written answer. In the second term their number almost doubled (an increase of 93 per cent). It is also evident that questions demanding a written answer are the dominant type of question. In 2004-2009, they accounted for 89 per cent of all questions; in 2009-2014 their share was even higher at 97 per cent of the total.

13 The Bonferroni correction divides the traditional level of statistical significance $\mathrm{p}<0.05$ by the number of tests carried out. If three groups are compared, the value is $p<0.02(0.05 / 3)$; when ten tests are performed, this value decreases to $p<0.005$, thus excluding results that would otherwise be considered of high statistical significance. 
Table 4. Total number of questions

\begin{tabular}{|l|c|c|}
\hline & $\mathbf{2 0 0 4 - 2 0 0 9}$ & $\mathbf{2 0 0 9 - 2 0 1 4}$ \\
\hline Oral questions & 399 & 787 \\
\hline Written questions & 27,648 & 53,262 \\
\hline • priority & 4,161 & 4,037 \\
\hline • non-priority & 23,487 & 49,225 \\
\hline Question Time & 3,089 & 715 \\
\hline Total & 31,136 & 54,764 \\
\hline
\end{tabular}

\section{Source: Authors}

The data above clearly indicate that the share of questions for written answer (non-priority ones) is so large that one may deduce that the groups' behaviour with respect to these questions will influence the results of the analysis for the whole population of parliamentary questions. This needs to be borne in mind whilst interpreting.

Our first analysis focused on the total number of questions. Beyond the coefficients of the Mann-Whitney $U$ test and its significance we also provide effect size. We report median values rather than averages, as the median is a more precise indication for non-parametric tests than the average (Field, 2009, p. 550). During the sixth term (2004-2009), the opposition (Mdn =25) posed statistically highly significantly more questions than the groups which made up the majority of the Commission ( $M d n=15), U=44,776.00, z=-4.11$. Effect size $(r=-0.14)$ was small. In the seventh term (2009-2014), the opposition $(\mathrm{Mdn}=54)$ again posed highly significantly more questions than the groups that made the majority in the Commission ( $M d n=37), U=49,667.00, z=-2.98$. Effect size $(r=-0.11)$ was again small. Thus, we note that at the most aggregate level there were very significant differences between the opposition and the majority in the Commission during both terms.

In the next step we analysed the various types of questions, including the two sub-types of written questions. We report the same data as in the first test: the coefficients of the Mann-Whitney U test, coefficient $\mathrm{z}$, the median and the effect size.

The analysis of the first type of question (to be answered orally) led to an interesting finding, which corrects the conclusion of the analysis of all questions. Whereas in the sixth term $(2004-2009)$, the opposition $(\mathrm{Mdn}=4)$ posed statistically highly significantly more questions than the groups that made up 
the majority in the Commission ( $\mathrm{Mdn}=2$ ), $\mathrm{U}=45,263.00, \mathrm{z}=-3.96$, the effect size $(\mathrm{r}=-0.14)$ was small, in the seventh term the situation changed. The groups which in 2009-2014 made up the majority in the Commission (Mdn =6) posed highly significantly more questions than the groups that were in opposition $(\mathrm{Mdn}=4), \mathrm{U}=48,880.00, \mathrm{z}=-0.28$. Effect size $(\mathrm{r}=-0.12)$ was small, as it had been during the sixth term.

When questions posed during Question Time were considered, no difference was found between the majority in the Commission and the opposition groups in either electoral term. During the sixth term (2004-2009), the opposition (Mdn $=1$ ) asked more questions than the groups that made up the majority in the Commission ( $M d n=0), U=54,351.00, z=-0.62$. The Mann-Whitney $U$ test, however, was not statistically significant $(\mathrm{p}=0.26)$. Despite the Mann-Whitney $U$ test, the assumption that the opposition would be the more active was confirmed. It remained so during the seventh term. The Mann-Whitney $U$ test was again not statistically significant $(\mathrm{p}=0.19)$, showing values of $\mathrm{U}=55,948.50$ and $\mathrm{z}=$ -0.91 . That the activities of the two groups were comparable is also shown by the median values for the opposition $(\mathrm{Mdn}=0)$ and "government" $(\mathrm{Mdn}=0)$.

The last set of tests undertaken was concerned with questions for written answer, where we differentiated between priority and non-priority questions. Among the former group (priority) the analysis showed the same results in both terms. In the sixth term (2004-2009) the opposition (Mdn =3) posed statistically highly significantly more questions than the groups which made up the majority of the Commission ( $M d n=2), U=49,234.00, z=-2.50$. Effect size $(r=-0.09)$ was small. In the seventh term, the opposition $(\mathrm{Mdn}=4)$ again posed statistically highly significantly more questions than the groups which made up the majority of the Commission ( $M d n=3), U=46,110.50, z=-4.33$. Effect size $(r=-0.16)$ was small.

Analysis of non-priority questions produced very similar results. In the sixth term $(2004-2009)$ the opposition $(\mathrm{Mdn}=10.50)$ posed statistically highly significantly more questions than the groups which made up the majority of the Commission $(\mathrm{Mdn}=7), \mathrm{U}=50,182.50, \mathrm{z}=-2.09$. Effect size $(\mathrm{r}=-0.07)$ was small. In the seventh term, opposition ( $\mathrm{Mdn}=34)$ again posed statistically highly significantly more questions than the groups which made up the majority of the Commission ( $\mathrm{Mdn}=24), \mathrm{U}=49,796, \mathrm{z}=-2.93$. The size of the effect ( $\mathrm{r}$ $=-0.16)$ increased, yet remained small. 
Table 5. Summary of analysis results

\begin{tabular}{|c|c|c|c|c|c|c|}
\hline & Total & $\begin{array}{c}\text { Written } \\
\text { answer - } \\
\text { Priority }\end{array}$ & $\begin{array}{c}\text { Written } \\
\text { answer } \\
- \text { Non- } \\
\text { priority }\end{array}$ & $\begin{array}{c}\text { Question } \\
\text { Time }\end{array}$ & $\begin{array}{c}\text { Oral } \\
\text { answer }\end{array}$ \\
\hline 2004-2009 & Opposition & + & + & + & $/$ & + \\
\hline & Commission & - & - & - & $/$ & - \\
\hline 2009-2014 & Opposition & + & + & + & $/$ & - \\
\hline & Commission & - & - & - & $/$ & + \\
\hline
\end{tabular}

Source: Authors

Summing up the results of our tests, we note that the opposition asked more questions in both terms (Table 5). At the aggregate level, the picture is crystal clear and this has been a medium-term trend. In a more nuanced perspective, which considers the fact that there are various types of parliamentary questions and that they may serve a variety of purposes, the conclusion is not simple. For two types of questions where one would expect the greatest difference-i.e. questions for oral answers and those posed during Question Time- there was either no discernible trend (i.e. the opposition/Commission groups changed their behaviour after 2009) or no difference. This could mean two things. One interpretation would suggest that the opposition changed between 2004-2009 and 2009-2014 and became less active. The second one could mean that the political groups supporting the Commission strategically asked more questions in the later period in order to balance the activity of opposition.

The expected differences are observable in the medium term in questions for written answers. However, these questions are less visible to the electorate, and less useful for gaining media exposure or for political competition, than oral questions or those asked during Question Time. On the other hand, MEPs can use information obtained via them for other purposes, for example in domestic competition. 


\section{Conclusion}

In a nutshell, the aim of our analysis was to ascertain whether a governmentopposition relationship could be explained by the use of parliamentary questions in the EP. We were also interested to know whether the political groups behaved consistently across the various types of parliamentary questions. Finally, we wished to ascertain whether there were medium-term trends in the groups' behaviour. We sought answers to these questions via an analysis of the datasets we have created, covering the parliamentary terms 2004-2009 and 2009-2014. Our analysis was conceived as exploratory rather than explanatory.

Answers to our questions depend on the scope of the data taken into consideration. At the aggregate level including all questions, the difference between opposition groups and those standing behind the Commission is statistically convincing. However, this is just a first sentence in the conclusion which provides additional questions rather than answers. First, knowing that aggregate level is heavily

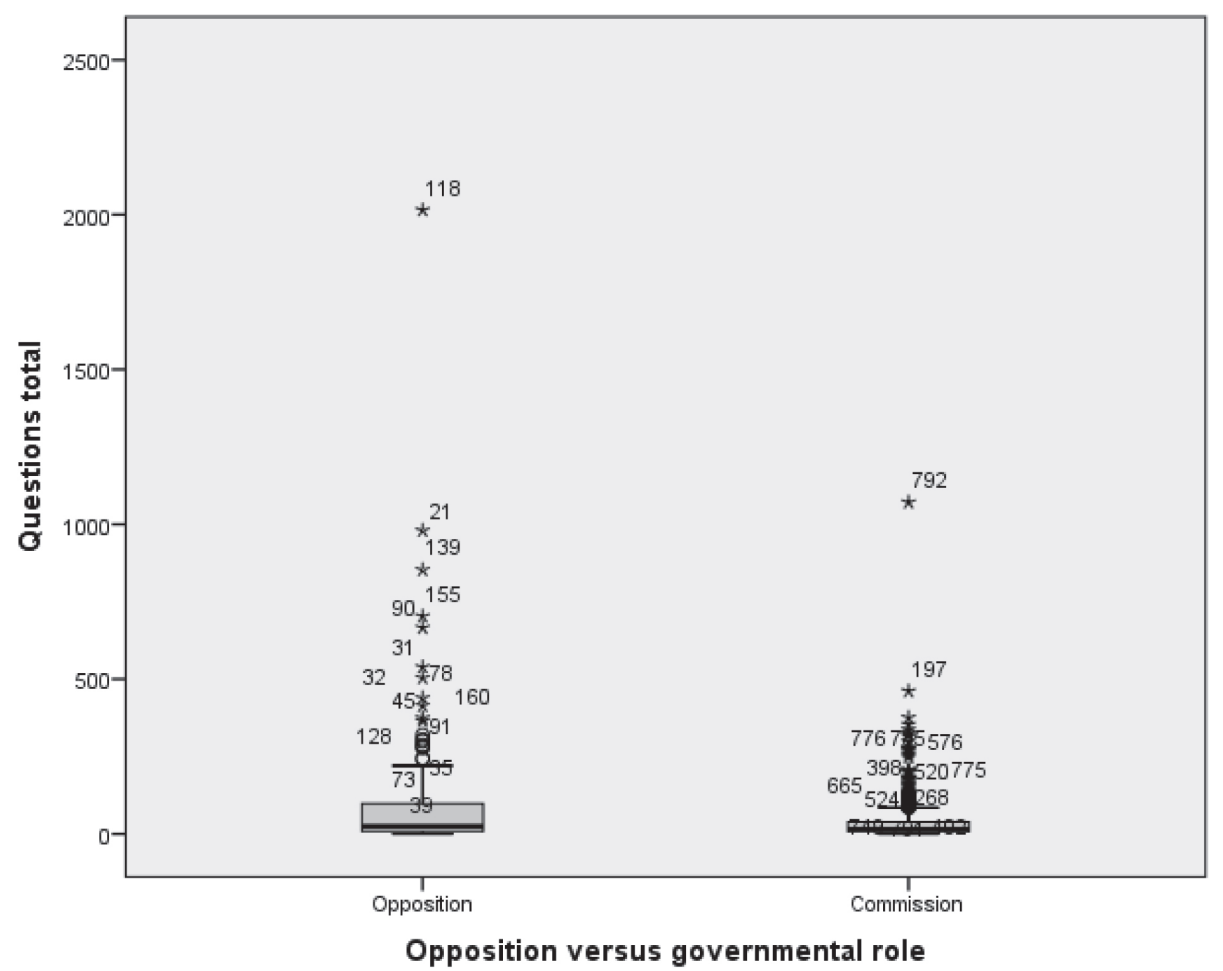

Figure 2. Boxplot detailing the use of parliamentary questions by MEPs, 2004-2009 
influenced by the amount of written questions - representing a very specific type of questions which are not addressed to the general public — raises a thought what difference at aggregate level tells us about the relation between opposition and groups represented in the Commission. Such doubts are even strengthened when examining the individual types of parliamentary questions, particularly those that are considered as the most important ones for parliamentary opposition. Here, no strong conclusion can be made, since the behaviour of the two camps changes over time and depends on the type of question. Quite surprisingly, particularly as far as the types of questions where opposition should be more active are concerned, its activity is smaller than in case of written questions. We suggest to understand this "deviance" as a consequence of EU level electoral and political system. MEPs in all Member States are still elected within their domestic constituencies whereas their activities - including questions asked by the opposition - address the EU level. Its visibility as well as attractiveness for the voters, however, is questionable. The distance - not only in geographical, but also in social terms - between "Brussels" and constituencies is remarkable, limiting the effect of particular tools which the opposition has at its disposal.

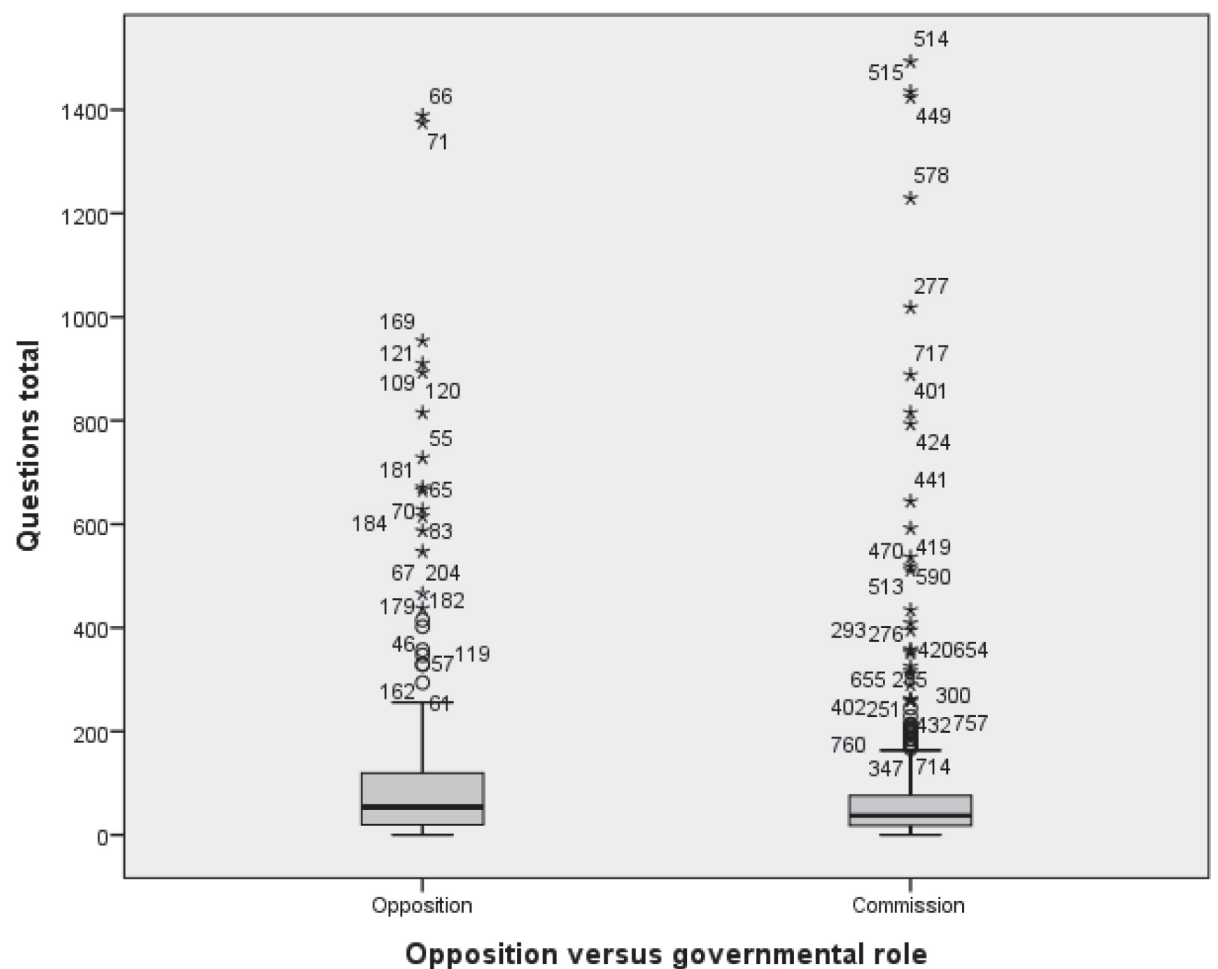

Figure 3. Boxplot detailing the use of parliamentary questions by MEPs, 2009-2014 
In this context, a broader use of written questions may make more sense for the opposition as they can provide knowledge that can be used further on.

It seems, therefore, that a better understanding of parliamentary questions in the EP would be facilitated by further analyses. Here we see two promising directions. The first one should target at the micro-level, i.e. one that considered individual MEPs as analytical units. The two boxplots we have created to outline homogeneity/heterogeneity within the two camps over the two terms suggest as much.

The two boxplots show that there were considerable differences between the MEPs of the two camps, and of the various groups, as evidenced by the substantial number of outliers in both the coalition and the opposition camps. This can be explained by the existence of particular MEPs who are within their groups responsible for posing questions. Even though this does not mean that other MEPs would be passive and do not ask questions at all, it suggests that variations among individual MEPs might be more interesting, and more telling, than variations among whole groups.

The need for micro-level research perspective is supported by another argument. Although our analysis was not explanatory by design, we believe that much of the turbulence in the relationship between opposition and coalition in the EP might be due to the MEPs' complicated position. They face more principals than just their political group in the EP. They divide their loyalty between this group (if they are members of one at all) and their national party or nation state, i.e. they are in the position of an agent with at least two principals. All these factors may affect an MEP's behaviour and these factors do not always act synergistically. In other words, the manner in which MEPs use parliamentary questions may well be influenced by variables outside the EP.

Furthermore, our analysis focused on the number of questions asked as the indicator leaving aside their content. In-depth research on topics covered by the questions could shed much light on the general role that questions play in the Parliament's political life. As we have found that political groups differ in their activities in numeric terms, we would expect the same difference to be found also in terms of the "quality" of questions asked. Detailed analysis of the content could shed more light on the purpose of why particular MEPs use a particular type of question and how they work with answers they get in their other political activities.

Apart from the two abovementioned suggested directions for further research we believe that future research should focus on the more nuanced conceptualisation 
of opposition in the EP. We are aware that there are more types of cleavages and the opposition-Commission division, on which our analysis is based, could be schematic. Therefore, another interesting avenue of future work could be an analysis of groups' behaviour within the notional clusters of opposition/ coalition in the Commission. For the opposition groups in particular, multiple perspectives could be adopted, of which the first could focus on their different positions on European integration, especially in terms of their varying types of party-based Euroscepticism. There are also differences among these groups in terms of their placement on the left-to-right spectrum, and the length of their tenure in the Parliament. Future research could also focus on another potentially useful parameter - the electoral system and national differences and traditions in relation to parliamentary questions. A preferential vote could imply the need to be better recognised by voters and citizens could be an important incentive to parliamentary questions. On the other hand, a special role of the MEP"questioner"- could exist in the EP.

\section{Acknowledgement}

This work was supported by the Grant Agency of the Masaryk University under grant MUNI/A/1113/2015.

Petr Kaniok works as an associate professor at the Department of International Relations and European Studies at the Faculty of Social Studies, Masaryk University. He focuses on the EU politics, particularly in its institutional dimension. His work has been recently published in East European Politics, European Politics and Society or Journal of Contemporary European Research.

Magda Komínková is a doctoral student at the Department of International Relations and European Studies at the Faculty of Social Studies, Masaryk University. Her research fields of interest are EU institutions, Euroscepticism and political parties. 


\section{References}

Akbaba, S. (2014), 'A critical assessment of a Eurosceptic party group on European integration: A case study of the European Conservatives and Reformists Group,' Baltic Journal of European Studies, vol. 4, no. 1, pp. 97-118. https://doi.org/10.2478/bjes-2014-0006

Brack, N. (2012), 'Eurosceptics in the European Parliament: exit or voice?' Journal of European Integration, vol. 34, pp. 151-168. https://doi.org/10.1080/07036337.2012.641087

Brack, N. (2015), 'The roles of Eurosceptic Members of the European Parliament and their implications for the EU,' International Political Science Review, vol. 36, no. 3, pp. 337-350. https://doi.org/10.1177/0192512115571590

Bressanelli, E. (2012), 'National parties and group membership in the European Parliament: ideology or pragmatism?' Journal of European Public Policy, vol. 19, no. 5, pp. 737-754. https://doi.org/10.1080/13501763.2011.646790

Bressanelli, E. (2013), 'Competitive and coherent? Profiling the Europarties in the 2009 European Parliament elections,' Journal of European Integration, vol. 35, no. 6, pp. 653-668. https://doi.org/10.1080/07036337.2012.711824

Consolidated version of the Treaty on European Union (2007), OJ C 115, 9.5.2008.

Corbett, R.; Jacobs, F. \& Shackleton, M. (2011), The European Parliament, 8th ed., London: John Harper Publishing.

Crespy, A. \& Gajewska, K. (2010), 'New parliament, new cleavages after the eastern enlargement? The conflict over the services directive as an opposition between the liberals and the regulators,' Journal of Common Market Studies, vol. 48, no. 5, pp. 1185-1208. https://doi.org/10.1111/j.1468-5965.2010.02109.x

Dahl, R. A. (1966), Political Oppositions in Western Democracies, New Haven: Yale University Press.

Demker, M. (2014), 'Sailing along new cleavages: understanding the electoral success of the Swedish Pirate Party in the European Parliament election 2009,' Government and Opposition, vol. 49, no. 2, pp. 188-206. https://doi.org/10.1017/gov.2013.24

Field, A. P. (2009), Discovering Statistics Using SPSS: (And Sex and Drugs and Rock ' $n$ 'Roll), 3rd ed., London: Sage Publications.

Finke, D. (2014), 'Domestic-level parliamentary scrutiny and voting behaviour in the European Parliament,' Government and Opposition, vol. 49, no. 2, pp. 207-231. https://doi.org/10.1017/gov.2013.27

Finke, D. (2015), 'Why do European political groups call the roll?' Party Politics, vol. 21, no. 5, pp. 750-762. https://doi.org/10.1177/1354068813509511

Gostyńska, A. (2014), 'The European Parliament and European Commission after the May elections,' The Polish Quarterly of International Affairs, Polski Instytut Spraw Międzynarodowych, vol. 23, no. 1, pp. 83-95. 
Helms, L. (2008), 'Parliamentary opposition and its alternatives in a transnational regime: the European Union in perspective,' The Journal of Legislative Studies, vol. 14, nos. 1-2, pp. 212-235. https://doi.org/10.1080/13572330801921208

Hirschman, A. O. (1970), Exit, Voice, and Loyalty: Responses to Decline in Firms, Organizations, and States, Cambridge, MA: Harvard University Press.

Hobolt, S. B. (2015), 'The 2014 European Parliament elections: divided in unity?' Journal of Common Market Studies, vol. 53, pp. 6-21. https://doi.org/10.1111/jcms. 12264

Jensen, C. B.; Proksch, S.-O. \& Slapin, J. B. (2013), 'Parliamentary questions, oversight, and national opposition status in the European Parliament,' Legislative Studies Quarterly, vol. 38, no. 2, pp. 259-282. https://doi.org/10.1111/1sq.12013

Judge, D. \& Earnshaw, D. (2008), The European Parliament, 2nd ed., Basingstoke: Palgrave Macmillan. https://doi.org/10.1007/978-1-137-07775-2

Kubát, M. (2010), Politická opozice v teorii a středoevropské praxi: (vybrané otázky) [Political Opposition in Theory and Central European Practices: (Selected Questions)], Praha: Dokořán.

Leconte, C. (2010), Understanding Euroscepticism, New York: Palgrave Macmillan. https://doi.org/10.1007/978-1-137-05633-7

Meijer, E. (2001), Written question E-2808/01 by Erik Meijer (GUE/NGL) to the Commission. 46,05\% structural exceeding of deadlines for replies to non-priority written questions, Parliamentary Questions, OJ C 115 E, 16.05.2002, p. 164.

Navarro, J. (2010), Questions in the European Parliament: What for? Preliminary Findings, Sciences Po Bordeaux: Spirit.

Raunio, T. (1996), 'Parliamentary questions in the European parliament: Representation, information and control,' Journal of Legislative Studies, vol. 2, no. 4, pp. 356-382. https://doi.org/10.1080/13572339608420492

Rozenberg, O. \& Martin, S. (2011), 'Questioning parliamentary questions,' The Journal of Legislative Studies, vol. 17, no. 3, pp. 394-404. https://doi.org/10.108 0/13572334.2011.595132

Russo, F. \& Wiberg, M. (2010), 'Parliamentary questioning in 17 European Parliaments: some steps towards comparison,' Journal of Legislative Studies, vol. 16, no. 2, pp. 215-232. https://doi.org/10.1080/13572331003740115

Sánchez de Dios, M. \& Wiberg, M. (2011), 'Questioning in European Parliaments,' The Journal of Legislative Studies, vol. 17, no. 3, pp. 354-367. https://doi.org/10.108 0/13572334.2011.595129

Sozzi, F. (2016), 'Electoral foundations of parliamentary questions: evidence from the European Parliament,' Journal of Legislative Studies, vol. 22, no. 3, pp. 349-367. https://doi.org/10.1080/13572334.2016.1202650

Švecová, V. (2010), European Parliament and its Supervisory Powers over the European Commission - An Excursion into Parliament's Task to Ensure Democratic Control over the Executive (Advanced Procedure), PhD thesis, Brno: Masaryk University. 
Treaty establishing the European Coal and Steel Community (1951), ECSC Treaty, 18.4.1951.

Volacu, A. (2012), 'Cooperation and competition in the European Parliament: a game theoretical interpretation,' Romanian Journal of European Affairs, vol. 12, no. 1, pp. 39-60.

Westlake, M. (1994), A Modern Guide to the European Parliament, London: Pinter Publishers.

Wiberg, M. (1994), Parliamentary Control in the Nordic Countries: Forms of Questioning and Behavioural Trends, Helsinki: Finnish Political Science Association. 